\title{
The Effect of Oil Price Shock and Inflation on Stock Returns: A Comparative Study on
}

\section{ASEAN-3}

Agatha Canonia Kristyaningrum ${ }^{1}$ and Hersugondo $^{2} \bowtie$

${ }^{1}$ Department of Management, Faculty of Economics and Business, Diponegoro University, Indonesia

${ }^{2}$ Department of Management, Faculty of Economics and Business, Diponegoro University, Indonesia

\section{Article Information}

\section{Article history:}

Accepted: September 2020

Approved: January 2021

Published: March 2021

Keywords:

Oil price shock

Inflation

Stock return

\begin{abstract}
This study aims to examine the effect of the WTI type oil price shock and inflation on stock returns from the ASEAN-3 capital markets, namely Indonesia, Thailand, and Philippines. The data used are monthly data from 2015 to 2019. The data analysis technique used is multiple linear regression. The results showed that oil price shocks had a significant positive effect on stock returns on the JASICA Mining index and the SET Resources index, but had no significant effect on the PSE Mining and Oil index. Furthermore, inflation had a significant positive effect on stock returns of Indonesia seen from the JASICA Mining index. Whereas, inflation had no significant effect on the SET Resources index of Thailand and the PSE Mining and Oil stock index of Philippines.
\end{abstract}

How to Cite: Kristyaningrum, A., \& Hersugondo, H. (2021). The Effect of Oil Price Shock and Inflation on Stock Returns: A Comparative Study on ASEAN-3. Jurnal Penelitan Ekonomi dan Bisnis, 6(1), 28 34. doi: https://doi.org/10.33633/jpeb.v6i1.3950 


\section{INTRODUCTION}

The economy of a country can be an indicator of the success of a country's economic development. The success of a country's development can be increased through the economic growth of a country. One of the components that can encourage the country's economic growth is the capital market. The growth of the capital market can affect macroeconomic indicators, including economic growth measured by gross domestic product (GDP). The country's economic development requires adequate financing to realize a good economic development in the country. The source of government revenue can be through taxes, capital market and money market.

Macroeconomic variables can affect the country's economy. According to Tandelilin (2010), stock returns can be influenced by microeconomic factors, such as financial and macroeconomic ratios. One of the macroeconomic ratios is inflation, which is a variable used in this study. An investor, when going to invest, needs to look at the factors considered as risk, both microeconomic and macroeconomic factors. According to Tandelilin (2010), macroeconomic factors are proven to have an influence on investment development in a country.

At present, the economic growth of a country is influenced by the presence of energy, one of which is crude oil. The role of energy is important because it can be an input that supports the production processes of companies in a country. The availability of good energy as input will result in a good output. The availability of good output has an impact on the country's sound economic growth. However, because world oil prices are not always stable, it can affect the country's economy. High inflation or even hyperinflation has a bad impact on the economy of a country. It causes the companies go bankrupt and make the company's stock price falling which is finally affect the stock returns received by investors.

The explanation of several things above was triggered by several things, one of which was reported by tirto.id (2017) when the ASEAN economic crisis that occurred in 1997, many ASEAN countries were in a bad condition. Starting from the Thai government, which issued a floating exchange rate policy against the baht currency with the aim of securing foreign exchange reserves and to stimulate income from export activities. However, these efforts failed to be achieved and resulted in an economic crisis that had a negative impact on the Asian region, particularly Southeast Asia and countries that were included in the Asian Economic Miracle countries. Continued in 2008, the world was hit by the global financial crisis, but the macroeconomic and political conditions in Southeast Asia were more ready than in 1997.The impact of the crisis was the depreciation of money which resulted in the price of imported goods becoming high value and demand for domestic production soaring, but the availability was not matched. This was followed by weakening purchasing power globally. In addition, it creates fluctuating and unstable inflation which causes the country's economic growth to be shaken.

This study aims to see the effect of oil price shocks and inflation of each country, namely Indonesia, Thailand and Philippines, on stock returns of each stock index related to the mining sector. Moreover, this study aims to assist investors in deciding their investment activities by looking at factors that can be considered as investment risks.

Arbitrage Pricing Theory (APT) is an asset pricing model and was first introduced by Ross in 1976. According to Lekovic (2017) APT makes a significant contribution to understanding the relationship between returns and risks in the capital market. The APT model is a multi-factor asset valuation model that is usually associated with macroeconomic factors and stock returns. APT is used in research because in APT it is necessary to identify risks that can affect stock returns, for example macroeconomic factors. One of the factors according to Solomon Brothers in Bina Ekonomi Magazine (2010) is that the rate of change in oil prices affect the stock returns. In addition, one of the macroeconomic factors commonly used in several studies using APT analysis is inflation according to Gusni \& Riantani (2017).

According to Harerio (2009) the multifactor model is a model that can be used to identify several economic factors that have a significant influence on investment risk, but analysts and investors cannot overcome this. There are two economic factors, namely microeconomics which focus on internal conditions and macroeconomics which focus on external factors, for example inflation, GDP, exchange rates or even world oil prices. According to Yustari (2010) the multifactor model can be used to describe the effect of various factor changes on the level of stock returns. The advantage of the multifactor model according to Bodhi (2009) in Yustari (2010) is that the model is better able to explain returns by identifying several factors than the single-factor model, in this study using two factors, namely oil price shock and inflation.

The effect of oil shock can have an impact on economic activity, one of which is on stock prices and leads to investment activities. The impact of rising oil prices or fluctuating prices can have a negative effect on stock prices and investment activities. Oil shock affects investment by increasing the cost of a company (Sadorsky, 1999; Kilian, 20019 and Henriques \& Sadorsky, 2011). 
According to Labonte (2011) inflation can be defined as a continuous increase in the price of goods in general, the increase in prices over a long period. The causes of inflation according to Suseno \& Astiyah (2009) are divided into three, namely demand inflation, supply inflation and expectation inflation.

\section{Hypothesis Development}

\section{Effect of Oil Price Shock on Stock Return of JASICA Mining Index}

According to Algia \& Abdelfatteh (2018) oil price shock can be caused by financial shocks which cause a decline in stock prices and affect the stock returns received by investors. Oktavia (2015) in Salim (2018) oil price shock can affect a company's finance in terms of production costs. The impact of an increase in production costs is an increase in product prices and a decrease in the profits received by the company which affects the stock prices and stock returns received by investors. This is supported by the results of research by Hadi, et al. (2009) and Sehgal \& Kapur (2012) showing that the oil price shock can affect stock returns from the Indonesian stock market index. Then the hypothesis is formulated as follows.

H1: Oil price shock has a positive effect on stock returns of JASICA Mining Index (IDX)

\section{The Influence of Indonesian Inflation on the Stock Return of JASICA Mining Index}

Tandelilin (2010) in Salim (2018) states that inflation is an increasing on price that occurs continuously which results in weak people's purchasing power. Inflation can affect the companies in producing goods. The companies might earn a small income which makes investors reluctant to invest in the company. The next impact is declining in the company's stock price which results in lower stock returns received by investors

Salim (2018) and Anisa \& Darmawan (2018) analyzed the influence of one of the macroeconomic factors, namely inflation on stock returns in the mining sector and the results explained that Indonesia's inflation had a significant negative effect on stock returns in the mining sector listed on the IDX. Through the existing explanations, the following hypothesis is formulated.

H2: Indonesia's inflation has a negative effect on stock returns on the JASICA Mining Index (IDX)

\section{Effect of Oil Price Shock on Stock Return of SET Resources Index}

Mugableh's (2017) research regarding changes in world oil prices on stock returns on the capital market in Southeast Asia shows that changes in world oil prices for the WTI type have a significant positive effect on the Thai capital market represented by the SET index. Furthermore, the research of Tchatoka, et al. (2019) regarding the effect of oil price shock on stock returns in the capital markets of countries that are quite dependent on world oil, one of which is Thailand and the result is that the oil price shock has a positive effect on the stock return of the Thai capital market. So, the following hypothesis is formulated.

H3: Oil price shock has a positive effect on stock returns on SET Resources Index (SET)

\section{The Influence of Thailand's Inflation on the Stock Return of SET Resources Index}

Research by Tarazi \& Gallato (2012) looks at the influence of macroeconomic factors, one of which is inflation on stock returns in the Thai capital market, the results show that inflation has a negative effect on stock returns on the Thai capital market. Furthermore, Wulandari (2015) examined the effect of monetary variables on the stock prices of the five ASEAN-5 stock indices, one of the variables is inflation and the results found that inflation has a negative effect on the SET Index stock price which will also have an impact on the SET Index stock return. So, the following hypothesis is formulated.

H4: Thailand's inflation has a negative effect on stock returns on the SET Resources Index (SET)

\section{The Effect of Oil Price Shock on the Stock Return of the PSE Mining and Oil Index}

Research by Nandha \& Hammoudeh (2007) shows the sensitivity of stock returns from 15 countries in the Asia Pacific region to changes in world oil prices. The results show that the Philippine capital market is very sensitive to changes in world oil prices. Thus, the result is that there is a significant positive relationship from changes in world oil prices to stock returns from the Philippine capital market. Furthermore, research by Aloui, et al. (2012) classifies the Philippines as a country that is quite dependent on world oil and this study proves that there is a significant and positive relationship between world oil price shocks and stock returns in emerging markets, one of which is the Philippine capital market. The hypothesis is formulated as follows.

H5: Oil price shock has a positive effect on stock returns on the PSE Mining and Oil Index (PSE) 


\section{The Influence of Philippine Inflation on the Stock Return of the Mining and Oil PSE Index}

Research by Ho \& Odhiambo (2018) which examines the inflation rate, developments in the banking sector, economic growth, exchange rates, and stock market liquidity on the growth of the Philippine capital market. Using ARDL analysis, the results of the study explain that inflation has a negative impact on the growth of the Philippine capital market because it has an impact on stock prices and stock returns. Another study from Carino, et al. (2013) which examines the effect of macroeconomic factors, namely the amount of money supply, interest rates, CPI (inflation), t-bills rate, PSEi stock price and exchange rate on stock returns on stock indices from the market. the capital of the Philippines. Analysis using VECM results that inflation negatively affects the stock return of the Philippine capital market index. Therefore, based on the previous explanation, the following hypothesis can be formulated.

H6. Inflation in the Philippines has a negative effect on stock returns on the PSE Mining and Oil Index (PSE)

\section{METHOD}

The data analysis technique of this research uses quantitative analysis with multiple linear regression which is processed using the EViews 10 application. The steps to carry out research data analysis are descriptive statistics, classical assumption tests consisting of multicollinearity test, autocorrelation test, normality test and heteroscedasticity test. Followed by hypothesis testing with the coefficient of determination (R2), simultaneous test (F test) and partial test ( $\mathrm{T}$ test).

The data used is secondary data sourced from Bloomberg, the investing website, the Bank Indonesia (BI) website, the trading economics website and the Philippine Statistics Authority website. The population of this study is the mining sector stock index price data published by the Indonesia Stock Exchange (IDX), the SET Resources index published by the Stock Exchange of Thailand and the PSE Mining and Oil index published by the Philippine Stock Exchange. In addition, the world oil price of West Texas Intermediate (WTI) type and inflation rates in Indonesia, Thailand and Philippines.

Selection of research samples using purposive sampling technique. The sample selection criteria that can be used as data for this research are the monthly closing price of WTI oil from January 2015 to December 2019, the closing price of the mining sector stock index on the IDX, the PSE Mining and Oil index from PSE and the SET Resources index. Then, the inflation data of Indonesia, Thailand and Philippines on a monthly basis from January 2015 to December 2019.

\section{RESULT AND DISCUSSION}

Table 1 below describes the results of descriptive statistics which include minimum value, maximum value, average, median, standard deviation, skewness and kurtosis.

Table 1. Descriptive Statistics Results

\begin{tabular}{c|c|c|c|c|c|c|c|c|c}
\hline \multirow{2}{*}{} & \multicolumn{3}{|c|}{ JASICA Mining Index } & \multicolumn{3}{c}{ SET Resources Index } & \multicolumn{3}{c}{ PSE Mining and Oil Index } \\
\cline { 2 - 10 } & $\mathrm{X} 1$ & $\mathrm{X} 2$ & $\mathrm{Y}$ & $\mathrm{X} 1$ & $\mathrm{X} 2$ & $\mathrm{Y}$ & $\mathrm{X} 1$ & $\mathrm{X} 2$ & $\mathrm{Y}$ \\
\hline Mean & 0.00094 & 0.0399 & 0.00435 & 0.00094 & 0.00375 & 0.00597 & 0.00094 & -0.0094 & 0.02497 \\
\hline Median & 0.00579 & 0.03405 & -0.0078 & 0.00579 & 0.004 & 0.01353 & 0.00579 & -0.0026 & 0.0245 \\
\hline Maximum & 0.09939 & 0.0726 & 0.24967 & 0.09939 & 0.0162 & 0.09875 & 0.09939 & 0.17334 & 0.067 \\
\hline Minimum & -0.1084 & 0.0248 & -0.1265 & -0.1084 & -0.0127 & -0.0938 & -0.1084 & -0.136 & -0.004 \\
\hline Std.Dev. & 0.04077 & 0.01372 & 0.06948 & 0.04077 & 0.00792 & 0.04684 & 0.04077 & 0.05876 & 0.01775 \\
\hline Skewness & -0.3504 & 1.43463 & 0.85799 & -0.3504 & -0.4899 & -0.2568 & -0.3504 & -0.0477 & 0.63584 \\
\hline Kurtosis & 3.44048 & 3.65913 & 4.1963 & 3.44048 & 2.29554 & 2.2151 & 3.44048 & 3.61409 & 2.78977 \\
\hline
\end{tabular}

Source: E-Views 10 output, processed 2020

Information :

$\mathrm{X} 1$ : Oil price shock

$\mathrm{X} 2$ : Inflation of each country

$\mathrm{Y}:$ Return stocks from each stock index 
Oil price shock has a skewness value of $-0,3504$ which indicates a negative value that can be interpreted that the data distribution has a long tail on the left side and kurtosis worth 3.44048 which has leptocurtic properties. Furthermore, Indonesia's inflation has a skewness value of 1.43463 which shows a positive value and means the data has a long tail on the right and kurtosis worth 3.65913 which means it has leptocurtic properties. Then, the stock return of JASICA Mining Index has a skewness value of 0.85799 which shows a positive value and is interpreted as having a long tail on the right and a kurtosis worth 4,1963 which means it has leptocurtic properties.

Furthermore, Thailand's inflation has a skewness value of -0.4899 which indicates a negative value which is defined as having a long tail value on the left and kurtosis having a value of 2,29554 which means having a platykurtic nature. Return on stock SET Resources has a value of skweness -0.2568 which has a negative value so it can be interpreted that the data has a long tail on the left and kurtosis has a value of 2,2151 which means it has platykurtic properties. Furthermore, Philippine inflation has a skewness value of -0.0477 which indicates a negative value, so it can be interpreted that the data has a long tail on the left and has a kurtosis value of 3.61409 which is leptocurtic because it has a value of more than 3. Finally, PSE Index stock return Mining and Oil has a skewness value of 0.63584 which indicates a positive value which means that the data has a long tail on the right and a kurtosis of 2.78977 which is platykurtic.

Hypothesis testing using the coefficient of determination (R2), $\mathrm{F}$ test and $\mathrm{T}$ test after the fulfillment of the classical assumption test which consists of normality test, autocorrelation, multicollinearity and heteroscedasticity are as follows.

Table 2 presents the results of the coefficient of determination which is useful for measuring how far the independent variable affects the dependent variable. The results obtained on the JASICA Mining Index have the meaning that the independent variables (oil price shock and inflation in the State of Indonesia) have an effect on stock returns of the JASICA Mining Index by $13.10 \%$, while at $86.90 \%$ other variables are obtained. Then, the SET Resources Index means that the independent variables (oil price shock and inflation in Thailand) have an effect on stock returns of the SET Resources Index by $23.45 \%$, while $76.55 \%$ is influenced by other variables. Finally, the PSE Mining and Oil Index means that the independent variables (oil price shock and inflation in the Philippines) have an effect on stock returns on the PSE Mining and Oil Index by $4.36 \%$, while $95.64 \%$ is influenced by other variables outside of the study.

Table 2. Determination Coefficient Test Results

\begin{tabular}{l|c}
\hline Index Name & Coefficient of Determination $\left(\mathrm{R}^{2}\right)$ \\
\hline JASICA Mining & 0,131015 \\
\hline SET Resources & 0,234481 \\
\hline PSE Mining and Oil & 0,043574 \\
\hline
\end{tabular}

Source: E-Views 10 output, processed 2020

Table 3 presents the results of the $\mathrm{F}$ test which is useful for seeing whether there is a significant effect of the independent variable on the dependent variable simultaneously. The results show that the JASICA Mining Index has a probability value of F-Statistic less than the significance value ( $\alpha=5 \%$ ), which is 0.018275 . It means that the oil price shock and inflation in the Indonesian State simultaneously have a significant effect on stock returns on the JASICA Mining Index. Furthermore, SET Resources Index has a probability value of F-Statistic less than the significance value, which is 0.000493 . It means that the oil price shock and inflation in Thailand simultaneously have a significant effect on stock returns on SET Resources Index. Finally, the PSE Mining and Oil Index has an FStatistic probability value of more than the significance level, which is 0.280910 . It means that the oil price shock and inflation in the Philippines simultaneously do not have a significant effect on stock returns on the PSE Mining and Oil Index.

Table 3. Simultaneous Test Results (F-test)

\begin{tabular}{l|c}
\hline Index Name & Prob. (F-Statistic) \\
\hline JASICA Mining & 0,018275 \\
\hline SET Resources & 0,000493 \\
\hline PSE Mining and Oil & 0,280910
\end{tabular}

Source: E-Views 10 output, processed 2020 
Table 4 presents the results of the $\mathrm{T}$ test which is useful for determining the effect of each independent variable on the dependent variable. The results of the JASICA Mining Index show that the oil price shock variable using a significance value of $10 \%$ has a significant effect on stock returns. JASICA Mining Index is evidenced by the prob value. The T-Statistic is less than the significance value. Indonesia's inflation has a significant effect on stock returns of JASICA Mining. Furthermore, the SET Resources Index shows that the oil price shock variable has a significant effect on stock returns of the SET Resources Index. However, inflation in Thailand has no significant effect on stock returns because it has a prob value. The T-Statistic is more than the level of significance. Finally, the PSE Mining and Oil Index states that the oil price shock variable does not have a significant effect on stock returns of the PSE Mining and Oil Index, as well as inflation in the Philippines also has no significant effect on stock returns on the PSE Mining and Oil Index as evidenced by the prob value. The T-Statistic is more than the level of significance.

Table 4. Partial Test Results (T-test)

\begin{tabular}{c|c|c|c|c|c|c|}
\hline \multirow{2}{*}{} & \multicolumn{2}{|c|}{ RETJM } & \multicolumn{2}{c|}{ RETSR } & \multicolumn{2}{c}{ RETPMO } \\
\cline { 2 - 7 } & OPS & INFIN & OPS & INFTH & OPS & INFIL \\
\hline Prob. t-Statistic & 0,0583 & 0,0630 & 0,0001 & 0,5769 & 0,1414 & 0,5766 \\
\hline Coefficient & 0,4110 & $-1,1985$ & 0,5458 & 0,3856 & 0,2786 & $-0,2409$ \\
\hline
\end{tabular}

Source: E-Views 10 output, processed 2020

\section{CONCLUSION AND RECOMMENDATION}

Hypothesis $1(\mathrm{H} 1)$ is proven, namely oil price shock has a significant positive effect on stock returns on the JASICA Mining index. Then, hypothesis $2(\mathrm{H} 2)$ is proven, Indonesia's inflation has a significant negative effect on stock returns on the JASICA Mining index. Furthermore, hypothesis 3 (H3) is proven, namely that the oil price shock has a significant positive effect on stock returns on the SET Resources index. Hypothesis 4 (H4) is not proven, because inflation in Thailand has no significant effect on stock returns on the SET Resources index. Hypothesis 5 (H5) is not proven, because the oil price shock has no significant effect on stock returns on the PSE Mining and Oil index. Finally, hypothesis 6 (H6) is not proven, because inflation in the Philippines has no significant effect on stock returns on the PSE Mining and Oil index.

The results of this study can provide as an input for investors who will carry out investments. Firstly, investors should be able to see the conditions of stock returns on each stock index. Secondly, investors should also be able to know and observe factors that affect stock returns from a stock index, including oil price shocks and inflation.

Further research can add other macroeconomic variables, apart from inflation which can affect stock returns. Besides that, it is can also include other countries in ASEAN, apart from only three countries, Indonesia, Thailand and the Philippines.

\section{REFERENCES}

Aloui, C., Nguyen, D. K., \& Njeh, H. (2012). Assessing the impacts of oil price fluctuations on stock returns in emerging markets. Economic Modelling, 29(6), 2686-2695.

Anisa, I., \& Darmawan, A. (2018). Pengaruh Ekonomi Makro dan Harga Komoditas Tambang Dunia terhadap Indeks Harga Saham Sektor Pertambangan di Indonesia. Jurnal Administrasi Bisnis (JAB), 56(1), 197-206.

Carino, C. J., Ong, C., \& Orbeta, M. C. (2013). Philippines: Time Series Analysis of Stock Market Returns and Their Macroeconomic Impacts for Years 2002 through 2011. (June).

Hadi, A. R. A., Yahya, M. H., \& Shaari, A. H. (2009). The effect of oil price fluctuations on the Malaysian and Indonesian stock markets. Asian Journal of Business and Accounting, 2(1-2), 69-91.

Hammami, \& Abdelfatteh, B. (2018). The Oil Price Shocks and their Effect on the Stock Market Returns : A Structural VAR Model. Journal of Economics and Economic Education Research, 19(3), 1-13. 
Henriques, I., \& Sadorsky, P. (2011). The effect of oil price volatility on strategic investment. Energy Economics, 33(1), 79-87.

Ho, S. Y., \& Odhiambo, N. M. (2018). Analysing the macroeconomic drivers of stock market development in the Philippines. Cogent Economics and Finance, 6(1).

Kilian, L., \& Park, C. (2009). The impact of oil price shocks on the U.S. stock market. International Economic Review, 50(4), 1267-1287.

Kusuma, F. P. P. (2015). Analisis pengaruh inflasi, suku bunga bi rate dan nilai tukar rupiah terhadap harga saham. Jurnal Ekonomi Bisnis, 1-15.

Labonte, M. (2011). Inflation: Causes, costs, and current status. Inflation and the Consumer Price Index: Costs and Considerations, 1-18.

Mugableh, M. I. (2017). World Oil Price Volatility and Stock Returns Fluctuations: Evidence from Southeast Asian Equity Markets. Sci.Int.(Lahore), 29(4), 759-762.

Nandha, M., \& Hammoudeh, S. (2007). Systematic risk, and oil price and exchange rate sensitivities in AsiaPacific stock markets. Research in International Business and Finance, 21(2), 326-341.

Pardede, N., Hidayat, R., \& Sulasmiyati, S. (2016). Pengaruh Harga Minyak Mentah Dunia, Inflasi, Suku Bunga (Central Bank Rate), Dan Nilai Tukar (Kurs) Terhadap Indeks Harga Saham Sektor Pertambangan Di Asean (Studi pada Indonesia, Singapura, dan Thailand Periode Juli 2013 â Desember 2015). Jurnal Administrasi Bisnis S1 Universitas Brawijaya, 39(1), 87417.

Salim, K. (2018). Analisis Pengaruh Harga Minyak Dunia, Inflasi, Tingkat Suku Bunga SBI, Kurs Rupiah/US\$ Terhadap Return Saham Sektor Pertambangan Yang Tercatat Di Bursa Efek Indonesia. Jurnal Ilmu Akuntansi Mulawarman, 4, 25.

Sehgal, S., \& Kapur, R. (2012). Relationship between Oil Price Shocks and Stock Market Performance: Evidence for Select Global Equity Markets. Vision: The Journal of Business Perspective, 16(2), 81-92.

Suseno, \& Astiyah, S. (2010). Seri Kebanksentralan No. 22 - Inflasi. Bank Indonesia, 22(22), 1-68.

Tarazi, R. E., \& Gallato, C. (2012). Determinants of Expected Stock Returns: Evidence from the Malaysian and Thai Markets. SSRN Electronic Journal, 1-12.

Tchatoka, F. D., \& Masson, V., \& Parry, S. (2019). Linkages between oil price shocks and stock returns revisited. Energy Economics, 82, 42-61.

Vu, T. N. (2019). Impact of crude oil price volatility on southeast Asian stock returns. Southeast Asian Journal of Economics, 7(2), 107-125.

Wulandari, Dwi. (2015). Pengaruh Beberapa Variabel Moneter Terhadap Harga Saham di Lima Negara Asean. Jurnal Ekonomi Kuantitatif Terapan, 7(2), 183-191. 